\title{
Coastal Community Group for Coastal Resilient in Timbulsloko Village, Sayung, Demak Regency, Indonesia
}

\author{
Hartuti Purnaweni ${ }^{1,2}$, Kismartini, ${ }^{1,2}$, Sudharto P. Hadi ${ }^{1,2,3}$, Ike Soraya ${ }^{4}$ \\ ${ }^{1}$ Master and Doctorate Program of Environmental Science, School of Post Graduate Studies, Diponegoro University, Semarang, \\ 50241, Indonesia \\ ${ }^{2}$ Public Administration Department, Faculty of Social Science and Political Science, Diponegoro University, Semarang, 50275, \\ Indonesia \\ ${ }^{3}$ Business Administration Department, Faculty of Social Science and Political Science, Diponegoro University, Semarang, 50275, \\ Indonesia \\ ${ }^{4}$ Alumni Master Program of Public Administration, Faculty of Social Science and Political Science, Dip onegoro University, \\ Semarang, 50275, Indonesia
}

\begin{abstract}
Coastal areas are very dynamic and fragile environment, demanding for polic ies to preserve these areas as materialized in the Resilient Coastal Development Program (PKPT) by the Indonesian government. Amongst the targeted area was Timbulsloko Village in Sayung District, Demak Regency, which coastal areas is severely damaged by erosion. This article analyzed the development of the Coastal Community Group (CCG) related to the PKPT program in Timbulsloko village, especially in how the group is empowered to increase the community's resilient in facing the disaster. This study, applied an analytical descriptive method, used the development of the CCG as phenomenon. Primary data was collected through observation and in-depth interviews with stakeholders, accompanying the secondary data. The result shows that the PKPT funding was mostly spent on infrastructure development and used for project management, not for optimizing local economic empowerment. After the completion of the PKPT, there are no actions or following programs to keep the physical results constructed by the CCG. Accordingly, the orientation towards the CCG building capacity for Timbuls loko community's ecological resilience had not been optimally implemented. This study recommended a "putting the last first" policy approach to preparing the local community. The government must play a stronger role in encouraging a self-help local group for strong human development
\end{abstract}

\section{Introduction}

Coastal areas are one amongst the most dynamic natural environments on earth, providing a range of goods and services that are very important to human social and economic existence. Coastal zones constitute the transitional area between the world's land and oceans, characterized by highly diverse ecosystems such as coral reefs, mangroves, and beaches. Since the beginning the mode of transportation was highly relied on sea transportation, therefore, coastal areas have been favorable for many people to live in, to take its benefit for food production, transportation, recreation and other human activities.

A large part of the global human population now lives in coastal areas: estimates range from $20.6 \%$ within $30 \mathrm{~km}$ of the sea to $37 \%$ in the nearest $100 \mathrm{~km}$ to the coast [1]. In 2010 a total of more than a billion people worldwide, most of them in Asia, live in lowlying coastal regions, within 20 meters of mean sea level on land measuring about 8 million square kilometers. It is roughly estimated that more than 200 million people worldwide live along coastlines, which is less than 5 meters above sea level. By the end of the 21 st century this figure is estimated to increase to 400 to 500 million [2].

Indonesia is a country that has huge potential in many sectors including fisheries and marine. This is an implication of Indonesia's characteristic as archipelago country. The potential is so large that should be utilized optimally for the welfare of its people, especially for communities in coastal areas. But in reality, these potencies can only be utilized about $20 \%$ alone that it brings a bad impact on coastal communities. This is seen from various problems hampering the people's welfare such as poverty, environmental degradation of coastal ecosystems, lack of organizational village selfsufficiency, and constraints of infrastructures [3]. The increasing problems in the coastal zones contributed to the high vulnerability to natural disasters and climate change in Indonesia, including in Java. Climate change is a crucial problem, both in impact and policy. Climate change does not appear on the "empty space," but it exists in socio-political context also [4]. This coastal degradation problem will more severe when it is doubled with climate change problem. 
One forms of environmental degradation is coastal erosion, including in Java, the mostly populated island in Indonesia. Central Java is the most degraded province in this case, figuring to 261.27 kilometers of impacted coastal area in 2014, followed by East Java (245.99 km2), West Java, Banten, and Jakarta [5] as can be seen in Figure 1.

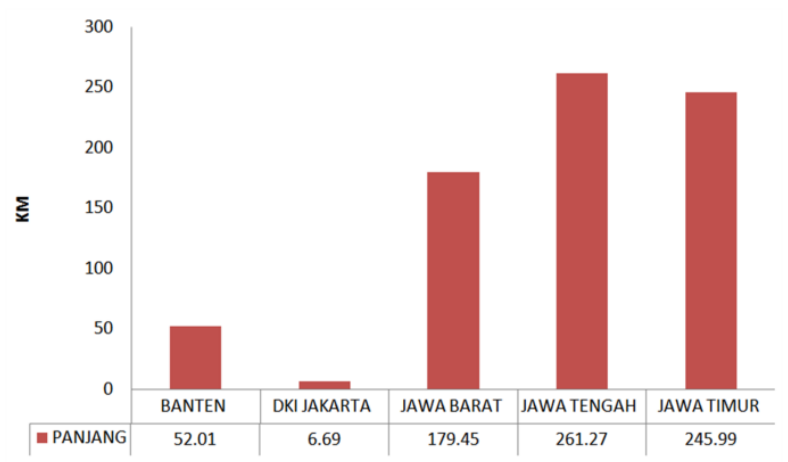

Fig. 1. Coastal abrasion in Java, 2014

One of the most vulnerable areas in the coastal area of Central Java is Demak Regency, especially in Sayung District [6], in which Timbulsloko village is one among the most severely affected by coastal erosion.

To address the high vulnerability of coastal villages to disasters, the government in this case the Ministry of Marine and Fisheries issued a policy in the form of Program Kawasan Pesisir Tangguh (PKPT) or the Resilient Coastal Development Program, which was stipulated in the Regulation of Minister of Marine Affairs and Fisheries Number 2/2013 on the Guidelines of the Implementation of the Self-Help National Program for Community Empowerment (PNPM Mandiri) of Marine and Fisheries. This program includes efforts to improve the resilience of coastal communities not only in terms of economy but also resilience to disaster. One of the villages appointed to implement the PKPT program is Timbulsloko village. Through the PKPT program, it is expected that the resilience and responsiveness of the community can be increased. Due to this, one among the program activities was the establishment of Coastal Community Group. This article analyzed the development of the Coastal Community Group related to the PKPT program in Timbulsloko village, especially in how the group is empowered to increase the community's resilient in facing the disaster.

\section{Methodology}

Location of this research was at Timbulsloko Village, Sayung District, Demak Regency which was severely affected by the erosion, therefore badly need disaster resilience program. The study applied an analytical descriptive method. The phenomena were the development of the Coastal Community Group. Primary data was collected through observation and in-depth interviews with stakeholders as most of them were mentioned by Kismartini et al [7], consisting of Head and staffs of Demak Regencial Office of Marine and Fisheries, Demak Regencial Government, Demak Regencial Office of Public Works, Head and staff of Timbulsloko Village Office, local community, members of the Coastal Community Group (CCG), and facilitators of the CCG. Meanwhile the secondary data was collected from various research results, GIS data, reports, maps, and files from various sources especially from Demak Regencial Office of Marine and Fisheries.

\section{Results and Discussion}

In the PKPT program, Human Development is one among its intended results, among which was facilitated with the establishment of Coastal Community Group, which is defined as organized group whose members live in coastal areas and practice commercial and noncommercial marine and fisheries activities related to environmental conservation [8]. This group was supported by a facilitator, which is a person which has educational background and competence in marine and fisheries, live in the benefited community, and responsible in accompanying the local community group during the program period [8] for increasing their resilient to disaster.

The term resilience is often used in the same manner as the notion of "bouncing back" that reflects its Latin root resiliere which means "to jump back" [9]. The concept of resilience originates three decades ago, in which Holling [19] is frequently cited as maybe the first to both use and define the concept of resilience in the field of ecology in his article entitled Resilience and Stability of the Ecological Systems. Holling defined the term resilience for an ecosystem as the measure of the ability of an ecosystem to absorb changes and still persist. He compared the concept of resilience with stability which he defined as the ability of a system to return to its equilibrium after a temporary disturbance. According to him, the more rapidly the system returns to its equilibrium, the more stable it is.

\section{Timbulsloko Village}

Timbulsloko village has 462.50 hectares of land area, with 3.5 kilometers coastal line since it is geographically located at coastal zone and directly bordered with Java Sea. Administratively this village is divided into 4 dukuh (sub-village) consisting of Wonorejo, Karanggeneng, Bogorame and Timbulsloko. Timbulsloko is 8 kilometers away from Sayung District office, and 17 kilometers from the capital of Demak Regency

Most of the villagers (49\%) were farmers, 33\% of which were labor-farmers. The farmers are fishpondfarmers, not those who work in the rice fields. In the second group were blue collar workers $(17 \%$ for industry, $13 \%$ for construction), followed by traders $(7 \%)$ and fishermen $(5 \%)[11]$. 


\section{Coastal Community Group for Ecological Resilience}

Abrasion which then causing inundated area constitute as a disaster in coastal areas such as Timbulsloko encouraged Ministry of Marine and Fisheries stipulated Resilient Coastal Development Program by among others establishing Coastal Community Group (CCG) to mediate development capacity of ecological resilient in the affected areas, including in Timbulsloko. This coastal group is a group of people who gather to help one another and cooperate in developing financial service source to encourage and to develop productive activities and enhancing standard of living among the members and their families. The community need to be gathered in group because it s difficult for the needy /the poor if they have to rely on themselves. Cooperation is hoped to be a better way to develop their economic condition.

The CCG is responsible for optimizing any resources provided in the Timbulsloko Village to minimize the disastrous impact of the abrasion, i.e. coastal inundation (local term: rob), which has caused economic and health losses as well as environmental damages. The PKPT in Timbulsloko has allowed the village to obtain financial assistance from the government towards further development efforts for human, environment, infrastructure, administration, and resilience [8]. Aided by facilitators, the CCG plays a significant role in (1) performing identification, selection, and verification of the CCG candidacy; (2) proposing the CCG candidacy verification results; (3) helping develop the RPKP plan; (4) prioritizing activities according to the existing RPDP documents; (5) facilitating the CCG in the RKK development; and (6) reporting.

Table 1. Community Involvement in CCG Samudera Jaya [12 and interview]

\begin{tabular}{|c|c|c|c|c|}
\hline No & Activity & $\begin{array}{l}\text { Target } \\
\text { Group }\end{array}$ & Total & $\begin{array}{c}\text { Forms of } \\
\text { Involve- } \\
\text { ment }\end{array}$ \\
\hline \multirow[t]{2}{*}{1} & \multirow{2}{*}{$\begin{array}{l}\text { Socializa } \\
\text { tion }\end{array}$} & Men & 4 & \multirow[t]{2}{*}{ Participant } \\
\hline & & Women & 3 & \\
\hline \multirow[t]{2}{*}{2} & \multirow{2}{*}{$\begin{array}{l}\text { CCG } \\
\text { Identifi - } \\
\text { cation }\end{array}$} & Men & 10 & \multirow{2}{*}{$\begin{array}{l}\text { Participant, } \\
\text { Executor, } \\
\text { Decision } \\
\text { maker }\end{array}$} \\
\hline & & Women & 3 & \\
\hline \multirow[t]{2}{*}{3} & \multirow{2}{*}{$\begin{array}{l}\text { Location } \\
\text { survey and } \\
\text { measure- } \\
\text { ment }\end{array}$} & Men & 3 & \multirow{2}{*}{$\begin{array}{l}\text { Participant } \\
\text { Executor }\end{array}$} \\
\hline & & Women & 1 & \\
\hline
\end{tabular}

During the CCG socialization the facilitators informed activity plan of the PKPT to all stakeholders at a village meeting. The meeting featured discussion of plan and evaluation of the rural development through vary funding schemes, CCG candidacies, terms and conditions and size of the group members. The committees and members of the CCG had to be natives as proven by their ID Cards. Furthermore, they could not be members if they were village government officers or staff, government apparatus or police/army members. There are 13 people in the group, $60 \%$ of which were, according to the standard, economically near-poor. CCG in Timbulsloko was then named "Samudra Jaya" (Wealthy Ocean)

However, in practice, the funding was more focused and prioritized on infrastructure development and used for project management. The fund is not optimized for economic empowerment. In Timbulsloko, most of the fundings were allocated to spending dumping materials of the local roads, in order to prevent these roads from flood during inundation. The group also bought a motor vehicle for collecting waste from households. The member group also joined field trips organized by the Demak Regencial government to visit Rembang Regency and Bali Province for learning about salt and mangrove cultivation. They also spent the money for joining carnival at Demak Regency [12]. Indeed, empowerment of the coastal communities should include comparative study and guided tour as suggested by the Ministry of Marine and Fisheries; however other programs such as economic trainings in terms of mangrove seedlings, processing of local product, or silvofishery should be given priority along with institutional building involving local government, village apparatuses and community groups [5].

After the completion of the projects in Timbulsloko, there are no actions or following programs to keep the physical results achieved by the Coastal Community Group. Therefore, when infrastructure development results deteriorated, there are no efforts to rebuild or rehabilitate. The waste motor vehicle was not operated anymore due to flood, lack of fund for gasoline, and miss management.

Even more, the CCG, which used to participate in the development, could no longer take action because it did not have any activity to offer. In the word, the group did not have any sustainability of actions and programs. There was not any economic activity supported through the PKPT scheme. The informants said that this was due the absence of any economic potential among the local communities that was worth of being developed.

Accordingly, the orientation towards the CCG building capacity for the ecological resilience for the local villagers of Timbulsloko had not been optimally implemented. The implication of such lackluster was high risk and disastrous impact of abrasion, i.e. coastal flooding. The local community resilience against the disaster was very low. Therefore, there is a need for alternative policy on improving the ecological resilience of the local villagers. Community's response and adaptive capacity is a one of the key roles on the disaster management and risk reduction program [13], therefore this has to be strengthened.

Assessing community resilience is a complex process because of the dynamic interactions of people, community, societies, and the environment. There are currently many conceptual frameworks proposed to measure this concept [9]. Generally, most of these frameworks conceptualize disaster resilience in the same way, in which they all focus on similar factors that could reduce vulnerability and increase community resilience. 
Such factors include economic resources, assets and skills, information and knowledge, support and supportive networks, access to services, and shared community values. These frameworks can be categorized as "community capital". The optimization of these communities' capital needs to be balanced. Coastal management policies must facilitate harmonic coexistence between human activities and the coastal system, between hard and/or soft components [13], relationship between natural resources and human resources [14]. The end results anticipated from the program is environmental sustainability and high responsiveness to disasters and climate change [15]. All stakeholders, consisting of coastal managers, ecologists, engineers, decision makers and society in general are jointly responsible of the future of the fragile and dynamic coasts [16], not only the fragile coastal community.

\section{Conclusions}

This study recommended a "putting the last first" policy approach to preparing the local community. The local government apparatus of Demak Regency and the rural government of Timbulsloko Village must play their role in performing a self-help institution promotion by taking measures from assistance, facilitation, to the promotion of the ecological resilience for the local villagers of Timbulsloko, especially in the establishment of the Coastal Community Resilience Group.

In term of institutional aspect this study recommended a community training towards the establishment of a sustainable disaster prevention group. To obtain the funding the group must be directed towards developing Village Income and Spending Budget (APBDes) to increase the funding allocation. The group is also expected to co-operate with private and other sectors.

\section{References}

1. RJT Klein, $\mathrm{PhD}$ Thesis for MathematischNaturwissenschaftliche Fakultat of the Christian Albrechts Universitat, Kiel University, Germany (2002), https://www.oceandocs.org/bitstream/handle/1834/ 789/Klein.pdf? sequence $=1$

2. World Ocean Review 1, Living with the oceans, $A$ report on the state of the world's oceans, (2010), http://worldoceanreview.com/en/wor$\underline{1 / \text { coasts/living-in-coastal-areas/ }}$
3. Y. Anggraeni et al, J Administrasi Publik, Vol 3:11, pp. 1862-1867 (2010)

4. Rusmadi, Sudharto P. Hadi, H.Purnaweni, Advance Science Letter, Vol 23:3 March (2017), pp. 25562558, https://doi.org/10.1166/asl.2017.8697

5. M.E Rudianto, Rencana Penanganan Kerusakan Pantura Jawa (Rehabilitation Plan for Java's Northern Coastal Area), Direktorat Pesisir dan Lautan, Kementerian Kelautan dan Perikanan (2015)

6. A.M. Marfai, Quaestiones Geographicae 31 (3), 2012, pp 47-55.

7. Kismartini, P. Hartuti, Sudharto P. Hadi, Proceeding ICM-MBT, pp 81-87, (2016) http://pksplipb.or.id

8. Direktorat Pesisir dan Lautan, KKP, Pedoman Teknis Pengembangan Kawasan Pesisir Tangguh (2015)

9. J. Mayunga, Understanding and applying the concept of community disaster resilience, https://www.ucursos.cl/usuario/3b514b53bcb4025a af9a6781047e4a66/

10. C.S. Holling, Annual Review of Ecology and Systematics, 4, 1-23 (1973)

11. Monografi Desa Timbulsloko (2015).

12. Pusat Penyuluhan Kelautan dan Perikanan, Badan Pengembangan SDM Kelautan Perikanan, KKP, Laporan Kegiatan PKPT Desa Timbulsloko Kecamatan Sayung Kabupaten Demak, (2015)

13. A.M. Marfai, and H. Diah, 2011, Seria Geografie Year XXI, no. 2/2011 (December), pp. 209-221 ISSN 1454-2749, E-ISSN 2065-1619 Article no. 212106-536.

14. M. A.Delgadillo-Calzadilla, E.Mendoza, R. Silva, J.A. Gonzalez-Vázquez, and D. Infante-Mata, J of Coastal Research Special Issue 71- Coastal Erosion and Management along Developing Coasts, (2014), pp. 114 - 121 , https://doi.org/10.2112/SI71-014.1.

15. Y.A. Supianto, BPBD Kabupaten Garut, http://www.garutkab.go.id/download_files/article/D esa-Tangguh-\%20Bencana.pdf

16. P. Hartuti, Kismartini, Sudharto P. Hadi, Tri R. Soeprobowati, Advance Science Letter, Vol 23 (3) March 2017, pp 2582-2583 https://doi.org/10.1166/asl.2017.8711.

17. M.L Martínez, R. Silva, D. Lithgow, E. Mendoza, P. Flores, R. Martínez, and C. Cruz, C., J of Coastal Research, Special Issue 77 pp. 143-153 (2017) 